\title{
Reported Skin Cancer Screening of US Adult Workers
}

\author{
William G. LeBlanc, PhD ${ }^{1}$, Liat Vidal, MD, MSc ${ }^{1}$, Robert S. Kirsner, MD, PhD ${ }^{2,3}$, David J. \\ Lee, PhD $^{1,2}$, Alberto J. Caban-Martinez, MPH ${ }^{1}$, Kathryn E. McCollister, PhD ${ }^{1}$, Kristopher L. \\ Arheart, EdD ${ }^{1}$, Katherine Chung-Bridges, MD, MPH ${ }^{1}$, Sharon Christ, MS ${ }^{5,6}$, John Clark III ${ }^{1}$, \\ John Lewis, PhD $^{4}$, Evelyn P. Davila, MPH ${ }^{1}$, Panta Rouhani, $\mathbf{M P H}^{1}$, and Lora E. Fleming, MD, \\ $\mathrm{PhD}^{1,2}$ \\ ${ }^{1}$ Department of Epidemiology \& Public Health, University of Miami Miller School of Medicine \\ ${ }^{2}$ Department of Sylvester Comprehensive Cancer Center, University of Miami Miller School of \\ Medicine \\ ${ }^{3}$ Department of Dermatology \& Cutaneous Surgery, University of Miami Miller School of Medicine \\ ${ }^{4}$ Department of Psychiatry, University of Miami Miller School of Medicine \\ ${ }^{5}$ Odum Institute for Research in Social Science, University of North Carolina at Chapel Hill \\ ${ }^{6}$ Department of Sociology, University of North Carolina at Chapel Hill
}

\section{Abstract}

Background-Early detection of skin cancer by skin examination may reduce its associated morbidity and mortality, in particular for workers routinely exposed to sun.

\begin{abstract}
Objectives-Describe the proportion of US workers reporting skin cancer screening examination in a representative sample of the US worker population in the National Health Interview Survey (NHIS).
\end{abstract}

\begin{abstract}
Methods-Report of skin cancer exam in the 2000 and 2005 NHIS cancer control supplements were examined by a range of variables.
\end{abstract}

Results-Lifetime and 12-month reported clinical skin examination prevalence was $15 \%$ and $8 \%$, respectively. Workers with elevated occupational exposure to UV light were less likely to have ever received a skin examination than the average US worker. Logistic regression analysis identified occupational category as well as age, sex, race, education level, health insurance, and sun protective behavior as significant independent correlates of skin cancer examination.

Limitations-Potential healthy worker effect and underestimation of skin cancer screening with self-reported data.

\footnotetext{
(C) 2008 American Academy of Dermatology, Inc. All rights reserved.

Corresponding Author: Lora E Fleming MD PhD, Department of Epidemiology \& Public Health, University of Miami Miller School of Medicine, 1801 NW 9th Avenue, Highland Professional Building, Suite 200, Miami, FL 33136, Phone: (305) 243-5912; Fax: (305) 243-5544, lfleming@med.miami.edu.

Publisher's Disclaimer: This is a PDF file of an unedited manuscript that has been accepted for publication. As a service to our customers we are providing this early version of the manuscript. The manuscript will undergo copyediting, typesetting, and review of the resulting proof before it is published in its final citable form. Please note that during the production process errors may be discovered which could affect the content, and all legal disclaimers that apply to the journal pertain.

Miami NIOSH Research Group Website: http://www.rsmas.miami.edu/groups/niehs/niosh/

Conflict of interest: All authors have no conflict of interest to disclose.

All authors have contributed significantly to the work, and have seen and approved the manuscript.
} 
Conclusions-Routine examination by primary care physicians frequently does not include a thorough skin exam. Physicians should be even more vigilant with patients at increased risk of excessive occupational sun exposure, as early detection of skin cancer by periodic skin examination decreases morbidity and can improve survival.

\section{Background}

The dramatic rise in skin cancer incidence coupled with the central role of primary care physicians in cancer prevention and detection has led many to emphasize the importance of periodic skin cancer screening in routine primary care.(1) Skin cancer is the most common form of cancer in the United States with over 1 million cases and approximately 10,850 deaths annually.(2-4) While the majority of skin cancers are basal cell and squamous cell carcinomas (non melanoma skin cancer), the fatality rate of melanoma is high and its incidence has risen more than 15-fold since reliable data were first recorded in the 1930s.(5)

Sun and other ultraviolet (UV) light exposures have been implicated as a major causal factor in two-thirds of skin cancer cases, particularly among some intense sun-exposure occupations as farming. $(6,7)$ Solar radiation, and UV light in particular, are increasing worldwide with the thinning of the protective ozone layer. $(2,8,9)$ The rising incidence of skin cancer over the past several decades may be attributed to increased sun exposure associated with societal, occupational and lifestyle shifts in the US population.

According to the governing principles of a worthwhile screening program, a disease considered for screening should have the following characteristics: high morbidity, mortality, costs, prevalence, and incidence; known natural history and biology; preclinical phase with high prevalence; and effective treatment of early-stage disease.(10) All 3 types of skin cancer possess all these characteristics: the prognosis for patients with early disease is excellent, early disease is often curable with simple surgical excision; therefore, early detection offers the opportunity to improve survival. $(4,11-13)$ Skin cancer risk factors are well known, and the full body skin examination as a skin cancer screening technique is safe, rapid, and easy to perform, making primary and secondary prevention obtainable and important.(14) Although evidence from randomized trials is non-conclusive, a case-control study suggested that skin self examination may lower the melanoma-related mortality rate, (15) and a recent cohort study showed that a thorough skin examination increased the likelihood of identifying suspected melanoma.(16) Screening and early detection are vital, particularly when performed on populations or population subgroups at higher risk.

Specific recommendations regarding skin cancer screening differ among several health policy groups. Several organizations, such as the American Academy of Dermatology, the National Institutes of Health Consensus Conference on Early Melanoma, and the American Cancer Society (ACS) favor population-based screening, in addition to screening for highrisk groups. In 2000, the ACS recommended skin cancer examination as part of a cancerrelated check-up every three years for people between 20 and 40 years of age, and annually for those over 40 years old; $(11,17,18)$ in 2005 , ACS recommended skin cancer examination during a periodic examination by a physician for people ages 20 and older (Table 1).(19-22)

Since approximately $85 \%$ of the population sees a physician every 2 years, primary care physicians have a unique opportunity to provide cancer screening and preventive services due to the large volume of patients seen during routine health examinations.(23) Nevertheless, studies have demonstrated that total body screening examinations are infrequently performed, even among potentially high risk populations.(24-27) To evaluate the extent of skin cancer screening among US workers, we used the National Health Interview Survey (NHIS) data to estimate the percentage of US workers who had ever had a 
thorough skin examination and among those who visited a primary healthcare provider in the past 12 months, to estimate the percentage that reported a skin examination during that period.

\section{Methods}

\section{Study Population}

The NHIS is an annual, cross-sectional in-person household survey of the US civilian noninstitutionalized population conducted by the National Center for Health Statistics (NCHS). The NHIS Cancer Control Module was administered in 2000 and 2005, and focuses on issues pertaining to knowledge and practices in cancer-related health behaviors. The NHIS Cancer Control Module is the only source of national population-based data on cancer screening. In 2000 and 2005, the Cancer Control Module included questions on clinical skin examinations which were administered to 19,702 and 18,422 employed participants, respectively. The conditional response rates to the 2000 and 2005 Sample Adult component of the NHIS (and for their Cancer Control Modules) were $82.6 \%$ and $80.1 \%$ respectively, and the final response rates were $72.1 \%$, and $69 \%$. Of the employed sub-sample adults, $96 \%$ and $94 \%$ responded to the specific skin screening question in 2000 and 2005, respectively (sub-sample $\mathrm{N}=18,965$ and 17,245, respectively). $(28,29)$

\section{Variables}

In both Cancer Control Modules, participants were asked: "Have you EVER had all of your skin from head to toe checked for cancer either by a dermatologist or some other kind of doctor?" The possible responses were: "Yes/No/Refused/Don't know." Participants were also asked: "When did you have your MOST RECENT skin exam?" We grouped data of all participants who reported a skin examination from head to toe during a) the last 12 months and b) ever in their lifetime. Of note, only those subjects who also reported seeing a primary care physician or OBGYN in the past 12 months were included in the participants reporting a skin exam in the past 12 months; all participants, regardless of seeing a physician in the past 12 months, were included in the reporting a skin exam in their lifetime.

In the Cancer Control Modules, participants were also asked about their sun protection behavior if they reported going out in the sun for an hour or more; those who responded "yes" were considered "sun exposed" for the purposes of this study. Among sun exposed participants, any participant who reported one or more of the following behaviors was considered to be "using sun protection" for the purposes of this study: a) wearing a hat that shades neck and face, $b$ ) wearing a long sleeved shirt, and/or c) using sun screen.

Detailed employment information coded by occupation and industry was collected on all subjects $\geq 18$ years reporting working (paid and unpaid) during the week before the NHIS survey.(30) This permitted a classification based on 2000 US Census Codes using a fourcategory occupational status variable commonly employed by the NCHS which included the categories of white-collar (Census codes 003-389), service workers (403-469), farming, fishing, and forestry (473-499), and blue-collar workers (503-889). We also grouped workers into eight industrial sector classifications which are now the focus of the National Occupational Research Agenda (NORA) at the National Institute on Occupational Safety and Health (NIOSH): Agriculture, forestry, fishing; Mining; Construction; Manufacturing; Wholesale, and retail trade; Transportation, warehousing, utilities; Services; and Healthcare and social assistance.(31-33) Of note, these industrial groupings ignore the type of work which is done in each sector such that each group may include workers engaged in both blue- and white-collar occupational activities. In 2000, forty-one standardized occupational codes derived from more detailed US Census occupational codes were provided; these codes 
changed significantly in 2005, not allowing for "cross walk" between 2000 and 2005 with regards to detailed occupation. Therefore, a more detailed occupational coding was only presented for the 2000 data.

\section{Statistical analysis}

Because of the complex sample survey design, analyses were completed with the SUDAAN package to take into account sample weights and design effects.(34) US worker population estimates were based on NHIS sampling weights and these estimates varied by non-response to specific screening questions. Screening prevalence are presented with standard errors and 95\% confidence intervals for the combined 2000 and 2005 cancer modules for the overall sample, and for the NCHS occupational categories and the NORA industrial sectors. Lifetime and past year screening rates were calculated for 41 occupational categories using the 2000 data. Of note, the prevalence rates presented in Table 2 were not adjusted for age to communicate the actual burden of disease in the population; age adjustment uniformly increased the prevalence by $1 \%$ (data not shown). We performed logistic regression analysis for the combined 2000 and 2005 cancer module data including the following variables: age (continuous and dichotomous [ $<40$ years; $\geq 40$ years]), sex, race (white, black, other), education (less than, equal to, or greater than 12 years), sun-protective behavior (as described above), and NCHS occupational status category. The study received an Exempt approval from the University of Miami Human Subjects Committee.

\section{Results}

Among 38,124 total worker participants interviewed from the 2000 and 2005 Cancer Control Supplements, 26,225 (69\%) reported seeing a primary care physician in the past 12 months; among these workers, 25,207 (96.1\%) answered "yes" or "no" to having received a skin cancer screening. The prevalence of both lifetime and 12-month skin exams were low (Table 2 and Table 3). Only 15\% of all US workers reported ever receiving a skin examination during their lifetime; only $8 \%$ of those who had also seen a healthcare provider in the past year reported that they had received a skin examination during the past year. Averaged over 2000 and 2005, approximately 106 million workers reported never having received a skin examination in their lifetime.

\section{2-month skin exam by occupational group (2000 and 2005 Cancer Control Module)}

In the 2000 and 2005 Cancer Control Modules, the prevalence of 12-month skin exam among those who had seen a physician in the past 12 months was lowest among farm workers $(5.8 \%, 1.6 \%$, respectively) and blue collar workers $(3.9 \%, 4.9 \%)$ (Table 2). Analysis by NIOSH-NORA industry sectors showed that Agriculture, forestry, fishing workers, and Construction workers reported the lowest rates of skin exam in 2000. While the prevalence of Agriculture, forestry, fishing workers reporting a skin exam rose from 2000 to 2005 (4.2\% to $13.6 \%$ ), the prevalence of skin exam among Construction workers stayed essentially the same (5.2\% to 5.6\%) (Table 2).

\section{2-month and lifetime skin exam by detailed occupational codes (2000 Cancer Control Module)}

In the 2000 Cancer Control Module among the 41 occupational groups, a lifetime history of ever having received a skin examination among all workers ranged from $3 \%$ in Forestry and fishing occupations to $32 \%$ of workers employed in the Health diagnosing occupations. Occupational groups at increased risk for job exposure to UV light were less likely to have ever received a lifetime skin examination than the average US worker, including: Farm operators and managers (10\%), Farm workers and other agricultural workers (7\%), Forestry and fishing occupations (3\%), Construction and extractive trades (8\%), and Construction 
laborers (8\%), although some estimates were unstable due to small samples size (Table 3). $(35-37)$

Prevalence rates for skin examination in the previous 12 months among workers with at least one healthcare encounter during the same time period was highest among workers employed in the Health diagnosing occupations (18\%). Workers employed as Material equipment moving operators, Construction workers, and Forestry and fishing occupations reported less than $1 \%$ skin cancer examination rates in the previous 12 months.

\section{Multi-variable logistic regression analysis}

The logistic regression analysis of the pooled data from the 2000 and 2005 Cancer Control Modules identified increasing age, male gender, white race, higher educational levels, having health insurance, and reporting the use of sun protective behavior as significant independent factors for having received a skin cancer examination in the past year (Table 4). Having controlled for these factors, Service, Farm, and blue collar workers compared to white collar workers were significantly less likely to report having had a skin exam. When the population was divided by $<40$ years and $\geq 40$ years of age, the patterns were the similar (particularly for the $\geq 40$ years of age subpopulation), although sometimes with less statistical significance due in part to a decreased sample size. Of interest, the effect of increasing education was particularly strong for the $<40$ year old population (education $>12$ years; Odds Ratio $=2.43 ; 95 \%$ Confidence Interval $=1.45,4.08$ ).

\section{Discussion}

Of 32,210 total US worker participants interviewed in 2000 and 2005 for which screening information was available, $70 \%$ reported seeing a physician in the past 12 months, while only $15 \%$ of these workers reported ever receiving a skin examination and only $8 \%$ received an examination in the past year. The rate of reporting skin cancer screening was lowest for high-risk occupations most likely to experience increased sun exposures. Occupational category as well as age, sex, race, education level, health insurance, and sun protective behavior were significant predictors of having a skin exam in the past year. Younger black or Hispanic females with no health insurance, who were Service, Farm or Blue Collar workers, and who did not use sun protection were the least likely to report ever having been screened for skin cancer. This is in concordance with the results of other reports of cancer screening. $(38,39)$

While the logistic regression analysis revealed the inverse association between blue collar, Farming and Service occupations and the rate of skin exam, the rates of screening in Table 2 demonstrate the actual public health burden. In the year 2000 population of an estimated $128,480,200$ US workers, an estimated $80,186,466$ workers who saw a healthcare provider reported not having received a skin cancer screening in the past 12 months. These are important results because recent research has demonstrated that even among workers with occupational high UV exposure, preventive practices are highly variable with little education and prevention policies in place in US workplaces.(36)

\section{Limitations}

The NHIS prevalence rates were based on self-report. It is possible that participants were unaware of having received a skin cancer screening, and thus the rate of screening might have been underestimated. However, self-reported whole-body skin examination has been validated in one study which reported a sensitivity of 90.5\%.(40) Studies have found the quality of doctor-patient communications is lower among less educated patients.(41) Therefore, a possible explanation for the lower rates of skin cancer screening among many 
of the blue collar occupational groups may be due to the communication challenges posed by differences in educational attainment between patient and health care provider. However, even after adjustment for educational level, the Service, Farming and blue collar workers were still significantly less likely to report skin cancer screening.

The NHIS uses information on the one week period prior to the survey for identification of occupation. Thus, individuals who did not work for the one week period prior to the survey are classified as "unemployed," and there may be misclassification of some workers who were on vacation or sick or on some other short-term leave from their jobs. Another limitation related to the use of the one week period prior to the survey is that the job worked for the past one week may not represent the longest or most important occupation during the lifetime of the individual. However, a previous study of the NHIS demonstrated a moderate to high agreement between current job and longest job held. (42) In that study, 70\% of occupational groups in the 13 occupational categories had Kappa values $\geq 50$ with regards to agreement between their current and longest-held job. Nevertheless this information on the working population is important as certain occupations experience constant high UV light exposure during their working life, and hence an increased risk of skin cancer. (35-37) Prevalence rates of skin cancer screening in those high risk populations were even lower than the average rate even among those who actually saw a physician.

Of note, the Guidelines refer to a "periodic skin examination," while using the NHIS data, we defined our variable as an examination in the last 12 months or "ever" skin exam. Yet it can be assumed that the results are not much different from the rate of "periodic" examination, as the rate of "ever" having a skin examination were relatively similar to that of having an exam in the last 12 months.

\section{Conclusions}

Recommendations from the ACS regarding screening for skin cancer include periodic skin cancer screening of people 20 and older, as well as health counseling about occupational exposures.(20) Skin examination by a healthcare provider on the occasion of a health examination, particularly among adult workers with high occupational sun exposure, can be preventative and curative for various types of skin cancer. However, routine examinations by primary care physicians and other healthcare providers frequently do not include a thorough skin exam. The rates of reporting screening skin exam in other studies range from $14.5 \%$ to $34 \% .(38,39)$ The American Academy of Dermatology and the American Medical Association have both provided brief review articles educating primary care physicians on efficient skin examination procedures for the office setting.(43)

Approximately $30 \%$ of workers in the present study reported no contact with the health care system in the previous 12 months, and workers without health insurance were at significant risk of not reporting a skin examination in the past 12 months or ever in their life. Therefore, recent declines in worker health insurance coverage will unfortunately ensure that millions of workers will continue to not receive skin examinations and other essential preventive services by primary health care providers. $(44,45)$ The results provided in this study could be used by public health officials, with the support of primary care physicians and other healthcare providers, to develop and implement local community health fairs specifically targeting the delivery of mass screening programs, as well as programs targeting high risk US worker groups (e.g., Construction, and Forestry, fishing, and farming workers) reporting low skin exams. Because they are community- and worksite-based, these programs could also be used to promote awareness and encourage access for US working adults to visit their primary care physician for general routine screening exams. The combination of increased 
workplace, as well as primary care office-based, and occupation-specific skin cancer screening, is needed to effectively address the skin cancer burden in the US.

\section{Acknowledgments}

Data for the NHIS were originally collected and prepared by the US Department of Health and Human Services and the National Center for Health Statistics (NCHS). The NCHS does not bear any responsibility for the analyses or interpretations presented in this publication. This study was funded in part through the National Institute of Occupational Safety and Health (grant \# R01 OH03915).

\section{Abbreviation and Acronym List}

$\begin{array}{ll}\text { ACS } & \text { American Cancer Society } \\ \text { NCHS } & \text { National Center for Health Statistics } \\ \text { NHIS } & \text { The National Health Interview Survey } \\ \text { USPSTF } & \text { The U.S. Preventive Services Task Force } \\ \text { UV } & \text { Ultra violet }\end{array}$

\section{References}

1. McDonald CJ. American Cancer Society perspective on the American College of Preventive Medicine's policy statements on skin cancer prevention and screening. CA: a cancer journal for clinicians. 1998 Jul-Aug; 48(4):229-231. [PubMed: 9676536]

2. Marks R. An overview of skin cancers. Incidence and causation. Cancer. 1995 Jan 15; 75(2 Suppl): 607-612. [PubMed: 7804986]

3. Fox AJ, Collier PF. Low mortality rates in industrial cohort studies due to selection for work and survival in the industry. Br J Prev Soc Med. 1976 Dec; 30(4):225-230. [PubMed: 1009272]

4. Greenlee RT, Murray T, Bolden S, Wingo PA. Cancer statistics, 2000. CA: a cancer journal for clinicians. 2000 Jan-Feb; 50(1):7-33. [PubMed: 10735013]

5. Howe HL, Wingo PA, Thun MJ, Ries LA, Rosenberg HM, Feigal EG, et al. Annual report to the nation on the status of cancer (1973 through 1998), featuring cancers with recent increasing trends. J Natl Cancer Inst. 2001 Jun 6; 93(11):824-842. [PubMed: 11390532]

6. Ramirez CC, Federman DG, Kirsner RS. Skin cancer as an occupational disease: the effect of ultraviolet and other forms of radiation. Int J Dermatol. 2005 Feb; 44(2):95-100. [PubMed: 15689204]

7. Thieden E, Philipsen PA, Sandby-Moller J, Wulf HC. Sunburn related to UV radiation exposure, age, sex, occupation, and sun bed use based on time-stamped personal dosimetry and sun behavior diaries. Arch Dermatol. 2005 Apr; 141(4):482-488. [PubMed: 15837866]

8. Kerr JB, McElroy CT. Evidence for Large Upward Trends of Ultraviolet-B Radiation Linked to Ozone Depletion. Science. 1993 Nov 12; 262(5136):1032-1034. [PubMed: 17782050]

9. McKenzie RL, Aucamp PJ, Bais AF, Bjorn LO, Ilyas M. Changes in biologically-active ultraviolet radiation reaching the Earth's surface. Photochem Photobiol Sci. 2007 Mar; 6(3):218-231. [PubMed: 17344959]

10. Clark R. Principles of Cancer Screening. Cancer Control. 1995 Nov; 2(6):485-492. [PubMed: 10825261]

11. Edman RL, Wolfe JT. Prevention and early detection of malignant melanoma. American family physician. 2000 Nov 15; 62(10):2277-2285. [PubMed: 11126854]

12. Kopf AW. Prevention and early detection of skin cancer/melanoma. Cancer. 1988 Oct 15; 62(8 Suppl):1791-1795. [PubMed: 3167795]

13. Almahroos M, Kurban AK. Ultraviolet carcinogenesis in nonmelanoma skin cancer part II: review and update on epidemiologic correlations. Skinmed. 2004 May-Jun; 3(3):132-139. [PubMed: 15133392] 
14. Kirsner RS, Federman DG. The rationale for skin cancer screening and prevention. The American journal of managed care. $1998 \mathrm{Sep}$; 4(9):1279-1284. [PubMed: 10185978]

15. Berwick M, Begg CB, Fine JA, Roush GC, Barnhill RL. Screening for cutaneous melanoma by skin self-examination. Journal of the National Cancer Institute. 1996 Jan 3; 88(1):17-23. [PubMed: 8847720]

16. Goldberg MS, Doucette JT, Lim HW, Spencer J, Carucci JA, Rigel DS. Risk factors for presumptive melanoma in skin cancer screening: American Academy of Dermatology National Melanoma/Skin Cancer Screening Program experience 2001-2005. Journal of the American Academy of Dermatology. 2007 Jul; 57(1):60-66. [PubMed: 17490783]

17. Mettlin C, Dodd GD. The American Cancer Society Guidelines for the cancer-related checkup: an update. CA Cancer J Clin. 1991 Sep-Oct; 41(5):279-282. [PubMed: 1878784]

18. Smith RA, Mettlin CJ, Davis KJ, Eyre H. American Cancer Society guidelines for the early detection of cancer. CA: a cancer journal for clinicians. 2000 Jan-Feb; 50(1):34-49. [PubMed: 10735014]

19. Smith RA, Cokkinides V, Eyre HJ. American Cancer Society Guidelines for the Early Detection of Cancer, 2005. CA: a cancer journal for clinicians. 2005 Jan-Feb; 55(1):31-44. quiz 55-6. [PubMed: 15661685]

20. Smith RA, Cokkinides V, Eyre HJ. Cancer screening in the United States, 2007: a review of current guidelines, practices, and prospects. CA: a cancer journal for clinicians. 2007 Mar-Apr; 57(2):90-104. [PubMed: 17392386]

21. Lee DJ, Gomez-Marin O, Prineas RJ. Type A behavior pattern and change in blood pressure from childhood to adolescence. The Minneapolis Children's Blood Pressure Study. Am J Epidemiol. 1996 Jan 1; 143(1):63-72. [PubMed: 8533748]

22. U.S. Preventive Services Task Force. Screening for Skin Cancer: Recommendation and Rationale. American Journal of Preventive Medicine. 2001; 20(35):44-46. [PubMed: 11306231]

23. Fletcher SW. The periodic health examination and internal medicine: 1984. Ann Intern Med. 1984 Dec; 101(6):866-868. [PubMed: 6497198]

24. Dolan NC, Martin GJ, Robinson JK, Rademaker AW. Skin cancer control practices among physicians in a university general medicine practice. J Gen Intern Med. 1995 Sep; 10(9):515-519. [PubMed: 8523156]

25. Federman DG, Kravetz JD, Kirsner RS. Skin cancer screening by dermatologists: prevalence and barriers. Journal of the American Academy of Dermatology. 2002 May; 46(5):710-714. [PubMed: 12004312]

26. Geller AC, Koh HK, Miller DR, Clapp RW, Mercer MB, Lew RA. Use of health services before the diagnosis of melanoma: implications for early detection and screening. J Gen Intern Med. 1992 Mar-Apr; 7(2):154-157. [PubMed: 1487762]

27. Kirsner RS, Muhkerjee S, Federman DG. Skin cancer screening in primary care: prevalence and barriers. Journal of the American Academy of Dermatology. 1999 Oct; 41(4):564-566. [PubMed: 10495376]

28. National Health Interview Survey (NHIS); Cancer Control Supplement (CCS). Providing National Surveillance in the Fight against Cancer. [cited; http://appliedresearch.cancer.gov/surveys/nhis/NHIS_fact_sheet.pdf] Available from:

29. Pleis JR, Schiller JS, Benson V. Summary health statistics for U.S. adults: National Health Interview Survey, 2000. Vital Health Stat 10. 2003 Dec.(215):1-132.

30. Caban AJ, Lee DJ, Fleming LE, Gomez-Marin O, LeBlanc W, Pitman T. Obesity in US workers: The National Health Interview Survey, 1986 to 2002. Am J Public Health. 2005 Sep; 95(9):16141622. [PubMed: 16051934]

31. Wagener DK, Walstedt J, Jenkins L, Burnett C, Lalich N, Fingerhut M. Women: work and health. Vital \& health statistics Series 3, Analytical and epidemiological studies / [US Dept. 1997 Dec. (31):1-91.

32. Fronczek, PO. US Dept of Commerce, Economics, and Statistics Administration, US Census Bureau. 2000. 2003 (http://purl.access.gpo.gov/GPO/LPS36316)

33. Sorerholm, SC. National Occupational Research Agenda. Cross-sector research in the second decade. Presented at the 2006 NORA Symposium. Presented at the NORA Symoposium WDCA; 
34. RTI. Software for Survey Data Analysis (SUDAAN) Release 8.0.0. Research. Triangle Park, NC: 2001.

35. Rushton L, Hutchings S, Brown T. The burden of cancer at work: Estimation as the first step to prevention Occupational Environment Medicine. 2008 Jan 31.

36. Glanz K, Buller DB, Saraiya M. Reducing ultraviolet radiation exposure among outdoor workers: State of the evidence and recommendations. Environmental Health. 2007; 6(22)

37. Kimlin M, Tenkate T. Occupational exposure to ultraviolet radiation: the duality dilemman. Rev Environmental Health. 2007; 22(1):1-37.

38. Saraiya M, Hall HI, Thompson T, Hartman A, Glanz K, Rimer B, et al. Skin cancer screening among U.S. adults from 1992, 1998, and 2000 National Health Interview Surveys. Preventive medicine. 2004 Aug; 39(2):308-314. [PubMed: 15226039]

39. Carriere P, Baade P, Newman B, Aitken J, Janda M. Cancer screening in Queensland men. The Medical journal of Australia. 2007 Apr 16; 186(8):404-407. [PubMed: 17437394]

40. Aitken JF, Youl PH, Janda M, Elwood M, Ring IT, Lowe JB, et al. Validity of self-reported skin screening histories. American journal of epidemiology. 2004 Jun 1; 159(11):1098-1105. [PubMed: 15155295]

41. Willems S, De Maesschalck S, Deveugele M, Derese A, De Maeseneer J. Socio-economic status of the patient and doctor-patient communication: does it make a difference? Patient Educ Couns. 2005 Feb; 56(2):139-146. [PubMed: 15653242]

42. Gomez-Marin O, Fleming LE, Caban A, Leblanc WG, Lee DJ, Pitman T. Longest held job in US occupational groups: the National Health Interview Survey. J Occup Environ Med. 2005 Jan; 47(1):79-90. [PubMed: 15643162]

43. O'Shea K, O'Connor P, Nucero BC. Research dissemination and utilization. N J Nurse. 2004 JulAug.34(5):11. [PubMed: 15508771]

44. Cohen, RA.; Martinez, ME. [Accessed November 17, 2005] Health Insurance Coverage: estimates form the NHIS Jan-March 2005. National Center for Health Statistics. 2005 September. 2005 http://www.cdc.gov/nchs/data/nhis/earlyrelease/insur200509.pdf

45. Reschovsky JD, Strunk BC, Ginsburg P. Why employer-sponsored insurance coverage changed, 1997-2003. Health Aff (Millwood). 2006 May-Jun; 25(3):774-782. [PubMed: 16684743] 
Table 1

Current and past American Cancer Society (ACS) and U.S. Preventive Services Task Force (USPSTF) screening guidelines applicable during the 2000 and 2005 National Health Interview (NHIS) Cancer Control Module surveys

\begin{tabular}{|l|l|}
\hline Advising Body, publication year & Guidelines \\
\hline ACS 2000 & $\begin{array}{l}\text { Examinations every 3 years from ages 20 to 39 years and annually } \\
\text { after age 40. The cancer-related check-up should include } \\
\text { examination for cancers of the ...skin }\end{array}$ \\
\hline ACS 2005 & $\begin{array}{l}\text { On the occasion of a periodic health examination, the cancer- } \\
\text { related check-up should include: Examination for check-up cancers } \\
\text { of the ...skin }\end{array}$ \\
\hline ACS 2007 & Same as ACS 2005 \\
\hline USPSTF 1995 http://odphp.osophs.dhhs.gov/pubs/guidecps/pcpstoc.htm & $\begin{array}{l}\text { There is insufficient evidence to recommend for or against either } \\
\text { routine screening for skin cancer by primary care providers.... A } \\
\text { recommendation to consider referring patients at substantially } \\
\text { increased risk of malignant melanoma to skin cancer specialists for } \\
\text { evaluation and surveillance may be made on other grounds }\end{array}$ \\
\hline USPSTF, current (updated 2001) & $\begin{array}{l}\text { The evidence is insufficient to recommend for or against routine } \\
\text { screening for skin cancer using a total-body skin examination for } \\
\text { the early detection of cutaneous melanoma, basal cell cancer, or } \\
\text { squamous cell skin cancer }\end{array}$ \\
\hline
\end{tabular}




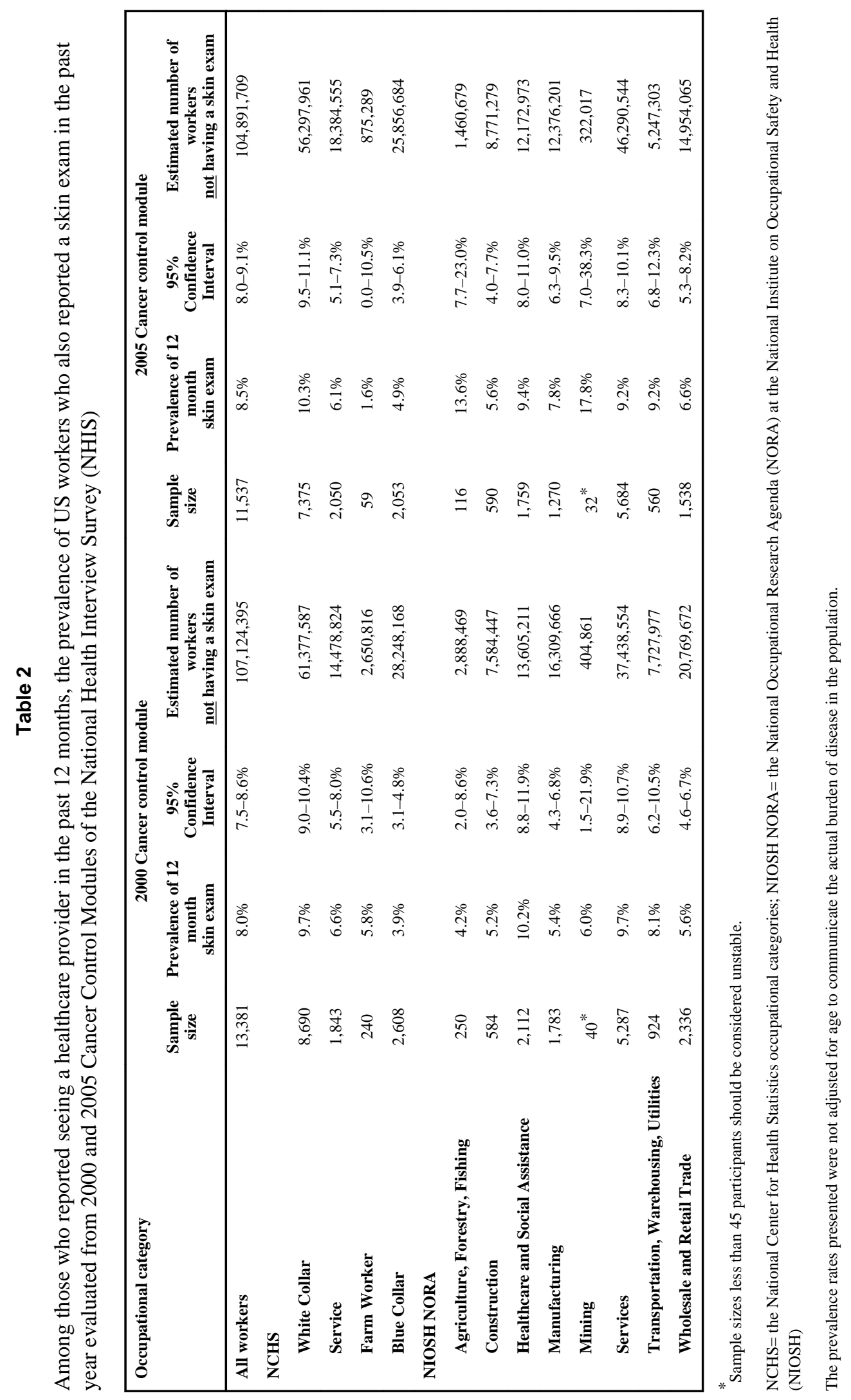


Table 3

Lifetime and previous 12-month self-reported medical skin cancer screening rates in 41 occupational groups (2000 Cancer Module of the National Health Interview Survey)

\begin{tabular}{|c|c|c|c|c|}
\hline Occupation & $\begin{array}{l}\text { Sample } \\
\text { size }\end{array}$ & $\begin{array}{c}\text { Estimated } \\
\text { worker } \\
\text { population }\end{array}$ & $\begin{array}{l}\text { Rate ever had } \\
\text { skin exam }\end{array}$ & $\begin{array}{c}\text { Rate skin exam } \\
\text { within past year }\end{array}$ \\
\hline Total & 18,965 & $123,958,606$ & $15 \%$ & $8 \%$ \\
\hline Construction laborers ${ }^{* *}$ & 140 & 903,160 & $8 \%$ & $0 \%$ \\
\hline Freight. stock, material handlers & 565 & $3,842,088$ & $5 \%$ & $3 \%$ \\
\hline Forestry and fishing occupations ${ }^{* *}$ & $19^{*}$ & 119,016 & $3 \%$ & $0 \%$ \\
\hline Farm workers and other agricultural workers ${ }^{* *}$ & 333 & $1,865,934$ & $7 \%$ & $6 \%$ \\
\hline Machine operators/tenderers, except precision & 718 & $4,561,694$ & $6 \%$ & $4 \%$ \\
\hline Mail and message distributing & 126 & 807,290 & $6 \%$ & $2 \%$ \\
\hline Private household occupations & 144 & 706,744 & $5 \%$ & $1 \%$ \\
\hline Fabricators, assemblers, inspectors, samplers & 391 & $2,574,917$ & $8 \%$ & $4 \%$ \\
\hline Construction and extractive trades & 785 & $5,545,136$ & $8 \%$ & $4 \%$ \\
\hline Material moving equipment operators & 137 & 889,278 & $7 \%$ & $0 \%$ \\
\hline Precision production occupations & 512 & $3,548,449$ & $8 \%$ & $5 \%$ \\
\hline Food service & 802 & $5,235,077$ & $7 \%$ & $5 \%$ \\
\hline Mechanics and repairers & 613 & $4,437,809$ & $9 \%$ & $5 \%$ \\
\hline Health service & 463 & $2,542,028$ & $9 \%$ & $7 \%$ \\
\hline Computer equipment operators & $38^{*}$ & 245,890 & $7 \%$ & $5 \%$ \\
\hline Motor vehicle operators & 571 & $3,975,045$ & $9 \%$ & $4 \%$ \\
\hline Other sales & 873 & $5,843,526$ & $10 \%$ & $6 \%$ \\
\hline Cleaning and building service & 520 & $3,085,558$ & $11 \%$ & $8 \%$ \\
\hline Farm operators and managers ${ }^{* *}$ & 120 & 891,435 & $10 \%$ & $6 \%$ \\
\hline Other protective service occupations & 153 & 918,247 & $13 \%$ & $6 \%$ \\
\hline Personal service & 454 & $2,693,371$ & $14 \%$ & $8 \%$ \\
\hline Other administrative support & 1,883 & $11,439,537$ & $14 \%$ & $9 \%$ \\
\hline Other transportation. except motor vehicles & $36^{*}$ & 298,271 & $12 \%$ & $14 \%$ \\
\hline Police and firefighters & 182 & $1,317,415$ & $14 \%$ & $8 \%$ \\
\hline Financial records processing occupations & 339 & $2,256,131$ & $11 \%$ & $5 \%$ \\
\hline Natural mathematical/computer scientists & 365 & $2,383,409$ & $14 \%$ & $9 \%$ \\
\hline Supervisors and proprietors & 581 & $3,924,582$ & $15 \%$ & $6 \%$ \\
\hline Technologists, technicians except health & 372 & $2,534,700$ & $16 \%$ & $9 \%$ \\
\hline Management related occupations & 770 & $5,092,138$ & $16 \%$ & $9 \%$ \\
\hline Engineers & 283 & $2,015,133$ & $16 \%$ & $9 \%$ \\
\hline Health technologists/technicians & 273 & $1,756,138$ & $17 \%$ & $11 \%$ \\
\hline Managers administrators, except public administration & 1,795 & $12,203,328$ & $19 \%$ & $11 \%$ \\
\hline Writers, artists, entertainers, athletes & 328 & $2,074,334$ & $20 \%$ & $12 \%$ \\
\hline Secretaries, stenographers and typists & 394 & $2,389,848$ & $18 \%$ & $11 \%$ \\
\hline Officials and administrators, public & 113 & 759,220 & $17 \%$ & $12 \%$ \\
\hline
\end{tabular}




\begin{tabular}{|lcccc|}
\hline Occupation & $\begin{array}{c}\text { Sample } \\
\text { size }\end{array}$ & $\begin{array}{c}\text { Estimated } \\
\text { worker } \\
\text { population }\end{array}$ & $\begin{array}{c}\text { Rate ever had } \\
\text { skin exam }\end{array}$ & $\begin{array}{c}\text { Rate skin exam } \\
\text { within past year }\end{array}$ \\
\hline Sales representatives, commodities and finance & 604 & $4,179,348$ & $23 \%$ & $13 \%$ \\
Teachers, librarians, counselors & 1,090 & $7,034,597$ & $21 \%$ & $12 \%$ \\
Architects and surveyors & $27^{*}$ & 153,838 & $25 \%$ & $6 \%$ \\
Health assessment/treating occupations & 494 & $3,269,480$ & $22 \%$ & $12 \%$ \\
Other professional specialty occupations & 416 & $2,613,951$ & $23 \%$ & $11 \%$ \\
Health diagnosing occupations & 143 & $1,031,516$ & $32 \%$ & $18 \%$ \\
\hline
\end{tabular}

Previous 12-month self-reported medical skin cancer screening rates were calculated of those workers who visited a physician in the past year; Lifetime self-reported medical skin cancer screening rates were calculated using all employed participants. Sample sizes were based on total working population in NHIS for 2000 Cancer Module.

* Sample sizes less than 45 participants should be considered unstable.

$* *$

Occupation at high risk for sun exposure 


\section{Table 4}

Among those who reported seeing a healthcare provider in the past 12 months, logistic regression analysis of the risk of having received a skin examination in the past 12 months (pooled data from 2000 and 2005 Cancer control modules of the National Health Interview Survey)

\begin{tabular}{|c|c|c|c|c|}
\hline \multicolumn{2}{|c|}{ Independent Variables } & \multicolumn{3}{|c|}{ Multivariate Adjusted Odds Ratios (95\% Confidence Intervals) } \\
\hline & & & $<40$ years $*$ & $\geq 40$ years ${ }^{*}$ \\
\hline Age (continuous) & Per year & $1.04(1.032,1.040)$ & & \\
\hline \multirow[t]{2}{*}{ Sex } & Male (reference category) & 1.00 & 1.00 & 1.00 \\
\hline & Female & $0.90(0.80,0.99)$ & $1.19(0.94,1.51)$ & $0.80(0.71,0.90)$ \\
\hline \multirow[t]{3}{*}{ Race } & White (reference category) & 1.00 & 1.00 & 1.00 \\
\hline & Black & $0.64(0.52,0.77)$ & $0.73(0.53,1.01)$ & $0.58(0.46,0.75)$ \\
\hline & Other & $0.56(0.41,0.75)$ & $0.63(0.38,1.03)$ & $0.52(0.36,0.75)$ \\
\hline \multirow[t]{3}{*}{ Education } & < 12 years (reference category) & 1.00 & 1.00 & 1.00 \\
\hline & $=12$ years & $1.11(0.85,1.45)$ & $1.41(0,81,2.47)$ & $1.01(0.74,1.39)$ \\
\hline & $>12$ years & $1.90(1.48,2.44)$ & $2.43(1.45,4.08)$ & $1.70(1.25,2.32)$ \\
\hline \multirow[t]{2}{*}{ Health insurance } & No (reference category) & 1.00 & 1.00 & 1.00 \\
\hline & Yes & $1.49(1.19,1.86)$ & $1.50(1.08,2.08)$ & $1.46(1.07,2.01)$ \\
\hline \multirow[t]{2}{*}{ Use sun protection } & No (reference category) & 1.00 & & 1.00 \\
\hline & Yes & $1.79(1.55,2.07)$ & $1.76(1.36,2.27)$ & $1.82(1.53,2.16)$ \\
\hline \multirow[t]{4}{*}{ NCHS occupation } & White collar (reference category) & 1.00 & 1.00 & 1.00 \\
\hline & Service workers & $0.84(0.70,0.99)$ & $0.91(0.69,1.20)$ & $0.80(0.65,1.00)$ \\
\hline & Farm workers & $0.52(0.26,1.06)$ & $0.55(0.12,2.47)$ & $0.50(0.23,1.12)$ \\
\hline & Blue collar & $0.54(0.44,0.65)$ & $0.57(0.39,0.83)$ & $0.53(0.42,0.66)$ \\
\hline
\end{tabular}

J Am Acad Dermatol. Author manuscript; available in PMC 2011 November 7. 